Journal of Applied Veterinary Sciences, 6 (2): 22 - 26 (2021).

ISSN: Online: 2090-3308, Print: 1687-4072

Journal homepage : https://javs.journals.ekb.eg

\title{
Focus on The Effect of Dietary Pumpkin (Cucurbita moschata) Seed Oil Supplementation on Productive Performance of Growing Rabbits
}

\section{Manal. R. Bakeer}

Department of Physiology, Faculty of Veterinary Medicine, Cairo University, Giza - 12211, Egypt.

"Corresponding Author, Manal. R. Bakeer, E-mail: manalbaker36@yahoo.com

\begin{abstract}
The present study was designed to investigate pumpkin seed oil's effect on body weight, digestive enzymes' activity, and the metabolic and antioxidant parameters of growing rabbits. This study was performed using two groups of 8-weeks old New Zealand White rabbits (NZW) ( $\mathrm{n}=10$ / each group). The experiment lasted for eight weeks. The animals were divided randomly to either the control group and fed on a basal diet (C) or the experimental with a basal diet supplemented with $5 \mathrm{~g}$ pumpkin seed oil $/ \mathrm{kg}$ diet $(\mathrm{P})$. Results revealed a significant increase in body weight, blood glucos levels, total lipids and total protein, and serum amylase activities, lipase, and protease. Significant improvements in the antioxidative parameters of rabbits were also observed. In conclusion, the benefits shown in this study support further research into the use of dietary supplementation with pumpkin oil for increasing productivity in growing rabbits.
\end{abstract}

Original Article:

DOI:https://dx.doi.org/10.21608/javs.202 $\underline{1.154577}$

Received :31 January, 2021. Accepted :22 February, 2021. Published in April, 2021.

This is an open access article under the term of the Creative Commons Attribution 4.0 (CC$\mathrm{BY}$ ) International License . To view a copy of this license, visit:

http://creativecommons.org/licenses/by/4.0/

Keywords: Digestive enzyme, , glucose, New Zealand White rabbits, pumpkin seed oil.

J. Appl. Vet. Sci., 6(2): $22-26$.

\section{INTRODUCTION}

Rabbit meat has long been recognized as a very important supply of animal protein to humans. Moreover, rabbits occupy a vital midway between ruminants and monogastric animals and can effectively utilize cellulose-rich feed with a ration containing less than $20 \%$ grain (Attia et al., 2012). Simple biological characteristics, short breeding cycle, high prolificacy and better feed conversion efficiency (Hasanat $\boldsymbol{e t}$ al., 2006). The importance of rabbits as an economic animal especially for meat production means the development of the gastrointestinal tract is vitally more important especially the mucosa (villous for absorption) and sub-mucosa (glands) for enzymatic digestion (EInasharty et al., 2013).

Dietary antioxidant factors have special importance in maintaining growth, reproduction and immune competence in animal production by reducing the deleterious effects of free radicals and toxic metabolites on animals (Peter, 2007). One of the wellknown natural antioxidants is pumpkin seed oil (Shaban and Sahu, 2017). Pumpkin seed oil is a rich natural source of proteins, phytosterols. Polyunsaturated fatty acids, antioxidant vitamins, such as carotenoids and tocopherol and trace elements, such as zinc (Makni et al., 2008).
The Pumpkin plant has been frequently used as a functional food or medicine (Caili et al., 2006). Pumpkin's consumption improves growth performance, milk yield and composition and reproductive performance of does as well as improving litter size and birth weight (Gaafar et al.,2014). In addition, pumpkin stimulates enzymes of animal digestive systems (Jamroz and Kamel, 2002; Ramakrishna et al., 2003).

There are few data available about the effect of Pumpkin Seed oil on productive performance of rabbit to our knowledge. We hypothesize that dietary Pumpkin Seed oil will enhance rabbit productive capacity. Therefore, this study's objective was to examine the effect of pumpkin seed oil on growing rabbits' productive performance.

\section{MATERIALS AND METHODS}

\section{Animals and Experimental Design}

The study was conducted in the Faculty of Veterinary Medicine, Cairo University. Twenty New Zealand white rabbits approximately eight weeks of age were divided randomly into two groups ( $\mathrm{n}=$ 10/group); one group was considered as a control group and fed on a basal diet (C), while the second group was fed the same basal diet supplemented with 5 g pumpkin seed oil/kg diet (P). Pumpkin seed oil was 
obtained from Arab Company for Pharmaceutical and Medicinal Plants, MEPACO", Egypt. The experiment lasted for 8 weeks. Rabbits were housed individually in commercial cages $(55 \times 60 \times 34)$, equipped with automatic drinkers and j-feeders. Clean and fresh water was always available.

The whole rabbitry was well ventilated with both natural windows and electric fans and illuminated to 14:10 light-dark cycle through natural and fluorescent lighting. Average ambient temperature and relative humidity ranged from $20-30^{\circ} \mathrm{C}$ and $70-80 \%$, respectively. Basal diet was formulated to meet rabbits' nutritional requirements as recommended in NRC (1977). Diets were subjected to chemical analysis according to AOAC (1997) and offered for all animals ad libitum.; Tables (1) \& (2).

Table 1: Composition percentage and analysis nutrients profile of the basal diet

\begin{tabular}{|l|c|}
\hline Ingredients & $\%$ \\
\hline Berseem hay & 30.0 \\
Barley grain & 21.0 \\
Yellow corn & 5.0 \\
Wheat bran & 21.1 \\
Soybean meal & 17.5 \\
Molasses & 3.0 \\
$\mathrm{CaCl}_{2}$ & 1.5 \\
$\mathrm{NaCl}_{\text {Vit.\&Min. Premix* }}$ & 0.4 \\
DL-Methionine & 0.3 \\
\hline Chemical analysis (\%)** & 0.2 \\
Moisture & \\
Crude protein & 9.4 \\
Crude fiber & 17.5 \\
Ether extract & 14.0 \\
Total Ash & 2.70 \\
Nitrogen free extract & 7.10 \\
Calculated digestible energy & 49.30 \\
(kcal/kg) & 2600 \\
\hline
\end{tabular}

*The Rabbit's vitamin and mineral premix/kg contained the following IU/g for vitamins or minerals: A-4,000,000, D3-5000,000, E-16,7 g, K-0.67 g, B1$0.67 \mathrm{~g}, \mathrm{~B} 2-2 \mathrm{~g}, \mathrm{~B} 6-0.67 \mathrm{~g}, \mathrm{~B} 12-0.004 \mathrm{~g}, \mathrm{~B} 5-16.7 \mathrm{~g}$, Pantothenic acid-6.67 g, Biotin-0.07 g, Folic acid-1.67 g, Choline chloride-400 g, Zn-23.3 g, Mn-10 g, Fe-25 g, Cu-1.67 g, I-0.25 g, Se-0.033 g, and Mg-133.4 g (Rabbit premix).

** Official methods of analysis of AOAC, international (1997).
Table 2: The chemical composition of pumpkin seeds oil

\begin{tabular}{|l|c|}
\hline \multicolumn{1}{|c|}{ Ingredients } & $(\%)^{*}$ \\
\hline Moisture & 5.52 \\
Protein & 25.4 \\
Fat (unsaturated fatty acid) & 2 \\
phytosterols & 33.9 \\
pectins & 1.16 \\
Minerals including zinc, iron, calcium, & 30.0 \\
magnesium, sodium, copper, & 4.0 \\
phosphorous and potassium. & \\
\hline
\end{tabular}

\section{Samples Collection and Analysis}

Blood samples were collected from the ear vein at the end of the experiment and immediately centrifuged at $1000 \mathrm{~g}$ for $10 \mathrm{~min}$ at $4{ }^{\circ} \mathrm{C}$. Serum was stored at $-20{ }^{\circ} \mathrm{C}$ until assayed for amylase activity using the method of Somogyi (1960). Lipase activity was assayed using the method described by Tietz and Fiereck (1966). Protease activity was analyzed using the method of Lynn and Clevette-Radford (1984). Blood glucose level was determined according to Tietz and Fiereck (1966), total lipids according to Allain (1974), and total protein according to Doumas et al., (1981). Serum superoxide dismutase activity (SOD) (Jewett and Rocklin, 1993), total antioxidant capacity (TAC) (koracevic et al., 2001) and lipid peroxidation expressed in Malondialdehyde (Yoshioka et al. 1979) were assessed using kits purchased from Biodiagnostic Company, Dokki, Egypt.

\section{Statistical Analysis}

Data were statistically analyzed using general linear models (GLM) procedures adopted by SPSS (2008) for user's guide with one-way ANOVA according to Snedecor and Cochran (1980).

\section{RESULTS}

The results summarized in table (3) show average bodyweight all over the experiment. Values indicate a significant increase in rabbits' average body weight fed the diet supplemented with pumpkin seed oil compared to controls.

At the end of the experiment, significant elevations were observed in blood glucose level, total lipids and total protein in rabbits supplemented with pumpkin seed oil compared to the control group (table 4). The results in table (5) indicate the activities of digestive enzymes in serum. The data show a significant increase in serum amylase activities, lipase and protease in rabbits fed the diet supplemented with pumpkin seed oil compared to controls. 


\section{Focus on The Effect of Dietary Pumpkin .....}

Table 3: Effect of pumpkin seed oil supplementation on body weight of rabbit (g)

\begin{tabular}{|ccc|}
\hline Parameters & Control group & Pumpkin group \\
\hline 8 weeks old & $1150 \pm 142.8$ & $1120 \pm 97.3$ \\
\hline 12 weeks old & $1540^{\mathrm{b}} \pm 84.5$ & $1780^{\mathrm{a}} \pm 105.2$ \\
\hline 16 weeks old & $1930^{\mathrm{b}} \pm 186.2$ & $2260^{\mathrm{a}} \pm 145.4$ \\
\hline
\end{tabular}

Values are means $\pm \mathrm{SE}$, (n: 10 rabbits / group).

Different superscript letters in the same raw denote $\mathrm{P}<0.05$ between treatments.

Table 4: Blood glucose, total lipids and total protein levels of rabbits supplemented with pumpkin seed oil

\begin{tabular}{|ccc|}
\hline Parameters & Control group & Pumpkin group \\
\hline Glucose $(\mathrm{mg} / \mathrm{dl})$ & $85.30^{\mathrm{b}} \pm 7.05$ & $120.10^{\mathrm{a}} \pm 8.24$ \\
\hline T. lipids $(\mathrm{g} / \mathrm{dl})$ & $225.10^{\mathrm{b}} \pm 19.20$ & $298.20^{\mathrm{a}} \pm 21.10$ \\
\hline T. protein $(\mathrm{g} / \mathrm{dl})$ & $4.72^{\mathrm{b}} \pm 0.67$ & $6.13^{\mathrm{a}} \pm 0.92$ \\
\hline
\end{tabular}

Values are means \pm SE, (n: 10 rabbits / group).

Different superscript letters in the same raw denote $\mathrm{P}<0.05$ between treatments.

Table 5: Serum activity of digestive enzymes in rabbits supplemented with pumpkin seed oil

\begin{tabular}{|ccc|}
\hline Parameters & Control group & Pumpkin group \\
\hline Amylase (U/L) & $118.30^{\mathrm{b}} \pm 9.04$ & $220.10^{\mathrm{a}} \pm 15.17$ \\
\hline Lipase (U/L) & $165.10^{\mathrm{b}} \pm 14.20$ & $228.50^{\mathrm{a}} \pm 11.10$ \\
\hline Protease (U/L) & $69.72^{\mathrm{b}} \pm 5.62$ & $96.93^{\mathrm{a}} \pm 4.87$ \\
\hline
\end{tabular}

Values are means $\pm \mathrm{SE}$, (n: 10 rabbits / group).

Different superscript letters in the same raw denote $\mathrm{P}<0.05$ between treatments.

Table 6: Impact of pumpkin seed oil supplementation on antioxidant parameters

\begin{tabular}{|ccc|}
\hline Parameters & Control group & Pumpkin group \\
\hline SOD $(\mathrm{U} / \mathrm{g})$ & $515.30^{\mathrm{b}} \pm 15.24$ & $660.10^{\mathrm{a}} \pm 16.35$ \\
\hline TAC $(\mu \mathrm{m} / \mathrm{L})$ & $2.05^{\mathrm{b}} \pm 0.12$ & $2.98^{\mathrm{a}} \pm 0.31$ \\
\hline MDA $($ 'nmol/g) & $15.32^{\mathrm{a}} \pm 1.60$ & $12.96^{\mathrm{b}} \pm 1.17$ \\
\hline
\end{tabular}

Values are means \pm SE, (n: 10 rabbits / group).

Different superscript letters in the same raw denote $\mathrm{P}<0.05$ between treatments.

SOD $=$ superoxide Dismutase.

TAC $=$ Total antioxidant capacity.

MDA $=$ Malondialdehyde. 


\section{DISCUSSION}

This study was designed to investigate the effect of pumpkin seed oil in improving rabbits' productive efficiency. The results revealed a significant increase in live body weight and blood glucose level, total protein and total lipid. These results agree with Gaafar et al. (2014) who reported that supplementation with pumpkin seed oil also increased rabbit body weight and some blood metabolic parameters. The results suggest that; these effects are possibly related to the high amount of protein and unsaturated fatty acids in pumpkin seed oil which important for animal body building (Gossell-Williams et al., 2006). Moreover, carbohydrate-rich pumpkin seed oil could have increased body weight by increasing blood glucose level and increasing metabolism (Salman et al.,2008). furthermore, the amino acid arginine, a biochemical precursor in the synthesis of many body proteins, is highly concentrated in pumpkin seeds, which is essential for body building (Abuelgassim, 2012).

Nakiae et al., (2006) found that pumpkin seeds' nutritional value is based on high protein content and a high percentage of oil. These oils include the fatty acids oleic (up to $46.9 \%$ ), linolenic (up to $40.5 \%$ ), palmitic and stearic acid up to $17.4 \%$. The pumpkin seed oil contains various minerals including selenium, zinc, calcium, copper, iron, manganese, phosphorous and potassium (4-5\%); and carbohydrate pectin (30\%). Pumpkin seed oil is rich in many potent antioxidants and beneficial nutritional supplements such as essential fatty acids and polyunsaturated fatty acids (PUFAs) including linoleic acid, oleic acid, palmitic acid, omega-3,omega-6 and omega-9, carotenes, lutein, gamma and P-tocopherols, phytosterols, chlorophyll, selenium and zinc and a reducer of heat stress that increases body weight and decrease animal mortality (Hajati et al., 2011).

According to the present study data, the activities of amylase, lipase and protease were significantly increased in serum of rabbits supplemented with pumpkin seed oil for 8 weeks. The results obtained by Al-Dabbas $\boldsymbol{e t}$ al. (2010) suggest that pumpkin seed oil increases the production of digestive enzymes and improves digestion products through the enhanced liver of poly-carboxylic acids, phosphate salts, fiber and proteins.

Rabbits supplemented with pumpkin seed oil showed a significant increase in antioxidant parameters and decreased lipid peroxide. The reported results confer with those of $\mathbf{X u}$ (2000), who found that pumpkin polysaccharides could increase SOD and GSH-Px activity and reduce MDA content in tumor mice serum. Moreover, Ahmed et al. (2009) reported that pumpkin seed oil administration resulted in a significant elevation in antioxidative adult male albino rats' antioxidative parameters. Aghaei et al. (2014) found that pumpkin seed oil improved antioxidant activity through increase serum TAC in the rat model, Similar to our findings but did not observe any effect on MDA in rats. However, Rouag et al., (2020) indicated that; pumpkin seeds (Cucurbita pepo L.) do decrease MDA in rats.

\section{CONCLUSION}

In conclusion, supplementation of growing rabbits with pumpkin seed oil was associated with improvements in live body weight through elevated blood glucose level, total protein and total lipid, and increased activity of the digestive enzymes. Additionally, pumpkin seed oil supplementation could be considered a beneficial tool for improving productive animal performance by increasing antioxidative parameters and decreasing animal stress. Therefore, the observed results suggest that pumpkin seed oil is a healthy addition to the rabbit diet, improving productivity.

\section{Declaration of competing interest}

There is no conflict of interest to declare

\section{REFERENCES}

ABUELGASSIM, T. 2012. The effect of pumpkin (Cucurbita pepo L) seeds and l-arginine supplementation on serum lipid concentrations in atherogenic rats. 9(1):131-137. http://dx.doi.org/10.4314/ajtcam.v9i1.18, 131.

AGHAEI, S., NIKZAD, H., TAGHIZADEH, M., TAMEH, A. A., TAHERIAN, A. AND MORAVVEJI, A. 2014. Protective effect of Pumpkin seed extract on sperm characteristics, biochemical parameters and epididymal histology in adult male rats treated with Cyclophosphamide. Andrologia, $\quad 46(8), \quad$ 927-935. https://doi.org/10.1111/and.12175.

AHMED, HH, ABDEL-RAHMAN, M., Ali, R.S. AND ABDEL MONIEM, A.E.2009. Protective effect of Ginkgo biloba extract and pumpkin seed oil against neurotoxicity of rotenone in adult male rats. J Appl Sci Res 2009;5(6):622e35.

AL-DABbAS, M. M., Al-ISMAIL, K., TALEB, R. A. AND IBRAHIM, S. 2010. Acid-base buffering properties of five legumes and selected food in vitro. Am. J. Agric. Biol. Sci., 5: 154-160. DOI: 10.3844/ajabssp.2010.154.160.

ALLAIN, C. 1974. Enzymatic determination of serum total lipids. Clin. Chem., 20:470-475.

AOAC, 1997. Association of Official Analytical Chemists International. Official Methods of Analysis,16th ed,3d revision, 1997, 41.1.36. AOAC

ATTIA, KA, SOHAIR, Y. SALEH., SAFAA, S. ABDELHamid., AMAL, A. Zaki. AND MOHAMED, A. SAWEE. 2012. Effects of exogenous multi-enzyme 
feed additive (Kemzyme) on the activities of certain digestive enzymes and intestinal morphology in growing rabbits Journal of Agricultural Science Vol.4, No.3.

CAILI, F., HUAN, S. AND QUANHONG, L. A. 2006. review on pharmacological activities and utilization technologies of pumpkin. Plant Foods Hum Nutr 2006; 61:73e80.

DOUMAS, B., BAYSE, D. AND CARTER, R. 1981. A candidate reference method for determination of total protein in serum. (I) development and validation. Clin. Chem., 27:1642-1650.

ELNASHARTY, M. EISharaby. AND NOR EL-DIN A. 2013. Histogenesis of Rabbit Vallate Papillae. International Journal of Animal and Veterinary Sciences. (2013) 7(4): 261-268.

GAAFAR, HMA, AYAT, A. RAGAB and. EI-REIDY, K.F.A. 2014. Effect of diet supplemented with pumpkin (Cucurbita moschata) and black seed (Nigella sativa) oils on the performance of rabbits: 2- Productive and reproductive performance of does and their offspring. Rep Opinion 2014;6(1):60-68. (ISSN: 1553-9873). http://www.sciencepub.net/report.

GOSSELL-WILLIAMS, M., DAVIS, A. AND O'connor, N. 2006. Inhibition of testosterone-induced hyperplasia of the prostate of Sprague-Dawley rats by pumpkin seed oil. J Med Food .9:284-286.

HAJATI, H., A. HASANABADI. AND WALDROUP, PW 2011. Effects of Dietary Supplementation with pumpkin oil (Cucurbita pepo) on performance and blood fat of broiler chickens during finisher period. American Journal of Animal and Veterinary Sciences, 6 (1): 40-44.

haSANAT, M. S., HOSSAIN, M. E., MOSTARI, M. P. AND HOSSAIN, M. A. 2006. Effect of concentrate supplementation on growth and reproductive performance of rabbits under rural conditions. Bangl. J. Vet. Med., 4 (2): 129-132.

JAMROZ, D. AND KAMEL, C. 2002. Plant extracts enhance broiler performance. In non-ruminant nutrition: Antimicrobial agents and plant extracts on immunity, health and performance. J. Anim. Sci., 80: 41. DOI: 10.3923/javaa.2009.2617.2620.

JEWETT, SL AND ROCKLIN, A.M. 1993. Variation of one-unit activity with oxidation rate of organic substrate in indirect superoxide dismutase assays. Analyst Biochem 212, 555-559. doi:10.1006/abio.1993.1368.

KORACEVIC, D. 2001. Method for the measurement of antioxidant activity in human fluids. J. Clin. Pathol. 54, 356-361.

LYNN, K. R. AND CLEVETTE-RADFORD, NA. 1984. Purification and characterization of hevin, a serin protease from Heveabrazilliensis. Biochem. J., 23:963-964.

MAKNI, M., FETOUI, H., GARGOURI, NK, El MGAROUI, JABER. H. AND MAKNI, J., et al. 2008. Hypolipidemic and hepatoprotective effects of flax and pumpkin seed mixture rich in u-3 and u6 fatty acids in hypercholesterolemic rats. Food ChemToxicol 2008;46:3714e20.
NAKIAE, SN, RADE, D., KEVIN, D., STRUCELJ, D., MOKROVE ak, Z. AND BARTOLIAE, M. 2006. Chemical characteristics of oils from naked and husk seeds of Cucurbita pepo L. Eur. J. Lipid Sci. Technol., 108: 936-943.

NRC "NATIONAL RESEARCH COUNCIL "1977. Nutrient Requirement of Rabbits (2nd ed.). National Academy of Science. Washington, DC., USA

PETER, FS 2007. Natural Antioxidants in Poultry Nutrition: New Developments. 16th European Symposium on Poultry Nutrition, pp: 669676.retreived from http://www.cabi.org/animalscience/Uploads/File/A nimalScience/additionalFiles/WPS .

RAMAKRISHNA, R. R., K. PLATEL. AND SRINIVASAN, K. 2003. In vitro influence of species and spice-active principles on digestive enzymes of rat pancreas and small intestine. Nahrung., $\quad 47$ : 408-412. DOI: 10.1002/food.200390091.

ROUAG, M., BERROUAGUE, S., DJABER, N., KHALDI, T., BOUMENDJEL, M., TAIBI, F., ABDENNOUR, C., BOUMENDJEL, A. AND MESSARAH, M. 2020. Pumpkin seed oil alleviates oxidative stress and liver damage induced by sodium nitrate in adult rats: Biochemical and histological approach. African Health Sciences, 20(1), 413-425. https://doi.org/10.4314/ahs.v20i1.

SALMAN, TM, OLAYAKI, LA AND OYEYEMI, WA 2008. Aqueous extract of Telfairia occidentalis leaves reduces blood sugar and increases haematological and reproductive indices in male rats. Afr J Biotechnol 7:2299-2303.

SHABAN, A., \& SAHU, R. P. 2017. Pumpkin Seed Oil: An Alternative Medicine. International Journal of Pharmacognosy and Phytochemical Research, 9(2).https://doi.org/10.25258/phyto.v9i2.8066

SNEDECOR, GM AND COCHRAN, WG 1980. Statistical analysis 7th ed, pp.215-237.

SOMOGYI, M. 1960. Modification of two methods for the assay of amylase. Clin. Chem., 6:23-27.

TIETZ, N. W., AND FIERECK. EA 1966. A specific method for serum lipase determination.Clin. Chim. Acta, 13:352-355. http://dx.doi.org/10.1016/00098981(66)90215-4nternational, Gaithersburg, MD.

Xu, G.H.2000. A study of the possible antitumour effect and immunom petence of pumpkin polysaccharide. J Wuhan Prof Med Coll 2000;28(4):1e4.

YOSHIOKA, T., KAWADA, K., SHIMADA, T. AND MORI, M. 1979. Lipid peroxidation in maternal and cord blood and protective mechanisms against activated oxygen toxicity in blood. Am J Obstet Gynecol, 135, 372-376.

How to cite this article:

Manal. R. Bakeer, 2021. Focus on The Effect of Dietary Pumpkin (Cucurbita Moschata) Seed Oil Supplementation on Productive Performance of Growing Rabbits. Journal of Applied Veterinary Sciences, 6 (2): $22-26$.

DOI: https://dx.doi.org/10.21608/javs.2021.154577 